\title{
THE FDM TECHNIQUE IN PROCESSES OF PROTOTYPING SPARE PARTS FOR SERVICING AND REPAIRING AGRICULTURAL MACHINES: A GENERAL OUTLINE
}

\author{
Krzysztof ŁUKASZEWSKI* \\ Faculty of Mechanical Engineering, Poznan University of Technology \\ Piotrowo 3 STR, 60-965 Poznan, POLAND \\ E-mail: krzysztof.lukaszewski@put.poznan.pl \\ Tatiana BUCHWALD \\ Faculty of Social Studies, University of Security in Poznań \\ Elizy Orzeszkowej 1 STR, 60-778 Poznan, POLAND \\ Radosław WICHNIAREK \\ Faculty of Mechanical Engineering, Poznan University of Technology \\ Piotrowo 3 STR, 60-965 Poznan, POLAND
}

\begin{abstract}
The aim of this research was to determine the possibility of applying alternative techniques for the production of prototypes for spare parts in agriculture and to determine the possible directions of development of their applications in the engineering industry. Then, to determine which spare parts could be produced using the FDM technique, comparisons of the most important parameters of spare parts produced independently (using the FDM technique) and obtained from producers (produced using traditional methods in professional factories) were made. A number of factors were analysed, from technical parameters such as machine type, processed material and its consumption including required as support structures, to economic issues such as manufacturing or purchase delivery total time and cost. The FDM technique has proven itself in many ways in the production of spare parts for agricultural machinery.
\end{abstract}

Keywords: FDM (Fused Deposition Modeling), FFF (Fused Filament Fabrication), 3D printing, spare parts, agricultural machinery, cost analysis.

\section{Introduction}

The FDM (Fused Deposition Modelling) technique is one of the most popular types of additive manufacturing. It is thanks to its most remarkable universality. Additive Manufacturing and 3D printing have brought about a revolution in how parts with complicated geometries can be manufactured with customized features. AM is one of the most fast-growing technologies in the current manufacturing industry due to its lesser product development time. This refers to a group of manufacturing processes where components are made layer-wire pattern directly from a CAD file. Compared to many other methods of additive manufacturing available on the market, only the FDM is characterized by the greatest availability, both in terms of price, as well as the required qualifications of the service and place where the machine can be used. Thanks to the use of composites, the mechanical properties of products manufactured using the FDM can be significantly increased $[1,2]$. 3D printing can be customized based on the requirements. These advantages and innovations in this field provided a wide range of applications. It is possible to find examples of FDM applications

\footnotetext{
${ }^{*}$ To whom correspondence should be addressed
} 
practically in every industry. The FDM method is most often applied in technical branches like automotive, construction, shipbuilding, aircraft, and medical industry [3, 4, 5].

Additive manufacturing is used not only for prototyping. At present, it is applied for producing small series of products or single parts, whose production would not be profitable with other methods. Producing objects when combining the FDM method and the technique of reverse engineering is justified where the demand for copying such objects exists in terms of the structure. The next advantage is the criterion of time, in cases of delivering a product or parts on time from the moment of the appearance of the demand (e.g., as a result of the breakdown). A combination of FDM possibilities and reverse engineering make it possible to construct improved products and to produce spare parts $[5,6]$.

Reverse engineering is a field of science for enabling producers to get the shape of real objects for the digital figure in the form of a three-dimensional model (3D). Highly specialised devices (e.g., optical scanners) and determined methods of engineering calculations are applicable to it. They allow the creation of the model of the virtual real object i.e. they make it possible to copy the surface of objects in the form defined as a triangular mesh or point cloud $[5,7,8]$. The model in such a form is usually sufficient to make a physical copy [9].

Actions connected with reverse engineering include data collection of geometrical, physical objects, reconstructing their geometry, and the data processing to the format accepted by CAD systems. In the process of constructing a physical object, there is an entrance element. A prototype, not being a final product or a model, can be the entrance element. The innovation of this field refers to enabling the examination of chosen features of objects in order to determine improvements in their work, their methodology, and technologies used in construction and reduction in production costs. That gives crucial information to creating duplicates and constructing models, in which it is possible to carry out an analysis of chosen indicators of the technical and economic evaluation, for example, a determined endurance of individual components and the entire part, the resistance to chemical substances, reactions to high and low temperature, flexibility, etc.

The FDM technique is based on using thermoplastic materials. In the original form, the material is wound onto a spool in the form of wire (filament). In the process of production, the material is supplied to the FDM machine, next is warmed, plasticised, and distributed layer after layer, according to the contour of the model transformed by an appropriate software. The material deposited through the nozzle cools and hardens. After deposition of a layer, the worktable is lowered or the head of the FDM machine rises to the height of the next layer, making space for the next portion of the thermoplastic material to be deposited $[4,10]$.

The polymers most often processed are ABS. For a hobby purpose also PETG and PLA are commonly used. Depending on the kind of the produced part and its allocating, the number and the sort of practicable materials can be more numerous. There is a possibility of applying materials marked by unique features, i.e. materials characterised by high impact strength, flexibility, resistance to determined temperature ranges or chemical compounds. Many accessible materials in the FDM method could successfully compete with materials applied in other production methods like injection moulding and thermoforming $[9,10]$. It is essential to point out that the material is characteristic of products made with the FDM technique, almost always will be worse than products from traditional production. The differences are not critically large. The speed of production and cost-effectiveness of FDM's single product constitutes the undoubted advantage, which compensates for reducing running characteristics [11].

PLA is a brittle, tough and fully biodegradable material obtained from renewable natural resources such as cornflour. Due to its low thermal shrinkage, it is usually used to produce larger-sized products. The ABS is useful for smaller products which should be characterised by an impact strength greater than PLA and with greater temperature resistance and extrinsic factors (like UV radiation). The ABS finds application most often in the spare parts of electronic apparatus, household appliances and car parts. The PETG ranks between the ABS and PLA. The PETG enables the production of durable products with cheaper machines that do not have a closed working chamber $[12,13,14]$.

In Poland, it is also possible to notice a growing interest in the possibilities of the FDM. Unfortunately, in many fields, this technique is still not known and not willingly adopted [2]. According to the authors, the great potential on that matter is placed in agriculture, in which it is possible to distinguish a lot of machines and devices constructed by using spare parts. Spare parts could be replaced systematically, according to current service needs, by substitutes from 3D printers. It is possible that parts produced with the FDM method with 
the worst running characteristics could be carried out through structural changes of spare parts, e.g. thicker walls or additional ribbing.

Polish domestic agriculture is an intensively developing branch of industry. In terms of cultivation techniques and technology as well as machines and tools used, Polish agriculture is constantly looking for new development paths, including maintenance service and spare parts. In addition, the analysis of economic profitability and ecological aspects of the agricultural activities has become more important [14]. Perhaps, with reference to the above, the method of producing agricultural machinery of spare parts, based on the existing ones, could constitute one of the possible solutions of producing spare parts in agriculture. Applying parts produced by the FDM method in the service will undoubtedly reduce the production time, which is vital from the point of view of agrotechnological periods. From this point of view, it is also important to repair or replace the damaged or worn spare part as soon as possible. For example, spraying against insects in rape should be carried out only in the evenings. The reason for this is the potential risk that the spraying during the day would harm the bees. It is also essential to conduct the entire spraying, preferably the same evening [15]. Of course, an interruption of work caused by damage of working parts will make this process impossible. In this case, a quick replacement of such a part is absolutely recommended. The standard logistic supply chain precludes the replacement in such a short time [14]. It should also be remembered that smaller farms incur higher costs of service upkeep. An equally important issue is the lack of long-term service support for machines currently not in the producer's sales offer.

The issues associated with the quality of service in agriculture. For decades are also of importance farming has been associated with the breeding of animals and the cultivation of plants, forgetting about the necessary machinery. Current agriculture of the 21 st century is a specific type of business activity, in which every management aspect is important and has a significant impact on the profit and loss for the financial year. From this perspective, modern farms and issues connected with them should also refer to issues related to quality engineering and quality management $[15,16,17]$.

In quality management models, more attention is focused on operational issues, primarily on basic processes, including design, maintenance and management improvement [16, 17]. Quality assessment, as well as concepts supporting management and a statistical essentialising of farm activity contribute to the development of farms. This applies especially to large-scale farms with numerous agricultural equipment. Therefore, applying the FDM technology in the service industry of agricultural machines is one of the directions of the subsequent development.

\section{Materials and methods}

The aim of the research was to analyse and determine whether it is possible to use the FDM technique in the process of servicing agricultural machines. The research problem was to consider an alternative for the spare parts available on the market. The mentioned substitutes were produced from universally available thermoplastic materials. The authors, examining the appropriability of the FDM technique, made an attempt to determine its suitability when the production of spare parts took place directly at a farm or a local service centre. The research was also aimed at checking the profitability of producing new parts compared to ordering them via online shops from Polish markets.

The scope of the research included:

1. Specification of agricultural machines' spare parts, which could be replaced with parts produced in the FDM technique. The spare parts are assumed to be made of polymer plastic materials.

2. Creating 3D models based on the real geometry of three selected parts.

3. Producing parts from three popular materials in the FDM technique: ABS, PLA, PETG.

4. Determining (for the three selected parts), average prices (including delivery costs) in online stores and estimating the price of produced parts, mainly on the basis of the materials used for their production (because the case of the budget of the FDM machines, this is a factor having a decisive impact on the total cost of production).

5. Summarising the prices obtained in order to determine the profitability of applying this method of production for spare parts. 
The market analysis focused on eight suppliers who sell by mail order and offer the option of ordering parts over the Internet. This paper presents three of them. They were characterised by a large number of offered products, and the analysed products were available at all three suppliers. The parts were selected on the basis of a practical example from a farm.

The exchange rate of the NBP [National Bank of Poland] of 2nd December 2020, is USD $1=P L N$ $3.6657[18]$.

Spare parts for a field sprayer and a seed drill have been chosen. Cost, time of production and delivery were evaluated to determine the effectiveness of the method. Based on comparisons, the advantages and disadvantages were indicated. A prognosis of the development of the discussed method in the future in Polish farming was determined. The limitations of the study included:

- only plastics spare parts, are analysed

- only the Polish reality, price and availability of parts, are token into account

- there were no analysis of the assortment of stationary stores.

\section{List of spare parts}

For the purposes of the research, a number of adequately selected tables presented below were made. Table 1 shows the minimum and maximum cost of delivery in selected shops. It is worth noticing that this cost depends on payment type, delivery time, and courier company. For low-value products, this can be an essential deciding factor.

Table 1. Comparative data of online shops and delivery cost $[19,20,21]$.

\begin{tabular}{|c|c|c|c|c|c|}
\hline Shop & Distributor & $\begin{array}{c}\text { Minimum } \\
\text { delivery cost }\end{array}$ & $\begin{array}{c}\text { Maximum } \\
\text { delivery cost }\end{array}$ & $\begin{array}{c}\text { Estimated } \\
\text { minimum } \\
\text { delivery time }\end{array}$ & $\begin{array}{c}\text { Estimated } \\
\text { maximum } \\
\text { delivery time }\end{array}$ \\
\hline I & $\begin{array}{c}\text { Agro-Bis Barszcz } \\
\text { Sp.J., } \\
\text { www.hurtowniarol } \\
\text { nicza.pl }\end{array}$ & $\begin{array}{c}20.00 \mathrm{PLN}, \\
5.45 \mathrm{USD}\end{array}$ & $\begin{array}{c}20.00 \mathrm{PLN}, \\
5.45 \mathrm{USD}\end{array}$ & 1 workday & 3 workdays \\
\hline \multirow{2}{*}{ II } & $\begin{array}{c}\text { MIZAR, } \\
\text { www.sklep.mizar. } \\
\text { com.pl }\end{array}$ & $\begin{array}{c}13.00 \mathrm{PLN}, \\
3.54 \mathrm{USD}\end{array}$ & $\begin{array}{c}26.00 \mathrm{PLN}, \\
7.08 \mathrm{USD}\end{array}$ & 1 workday & 3 workdays \\
\hline \multirow{2}{*}{ III } & $\begin{array}{c}\text { AGROKOM, } \\
\text { www.sklep- } \\
\text { rolnicze.eu }\end{array}$ & $\begin{array}{c}8.50 \mathrm{PLN}, \\
2.32 \mathrm{USD}\end{array}$ & $\begin{array}{c}20.00 \mathrm{PL}], \\
5.45 \mathrm{USD}\end{array}$ & 1 workday & 3 workdays \\
\hline
\end{tabular}

In the next step of the research, a list of selected spare parts for agricultural machines was made. Only those made of polymer plastics were considered. The majority of parts listed in Tab.2. were available in online shops described in Tab.1. There is a large number of parts for agricultural machines which could be produced with the FDM method, compared to the selection available in two shops (also in comparison to their prices). The authors observed that in online shops, a large number of parts was available only in one shop, and there was no equivalent or substitute in another. This constitutes an inconvenience in the case of ordering several parts from one supplier.

Table 3 lists the parts selected for the FDM production. Parts were chosen on the basis of the work environment. For example, part No. 1 is used to pass grains in a seed drill in a dry work environment. Part No. 14 is used in a field sprayer, which has direct contact with the operator and is located outside the machine, so it is directly exposed to a variety of weather conditions. Part No. 15 is inside a field sprayer tank in a wet work environment. In Tab.3., prices of these parts were also given. In the last part of this article, the average prices of each part were compared with the cost of producing spare parts in the FDM method. 
Table 2. Analysed spare parts and their intended use in agricultural machinery.

\begin{tabular}{|l|l|l|}
\hline No. & Intended use & Spare part \\
\hline 1 & seed drill Unia Poznaniak & seed metering wheel (hexagonal hole - socket) \\
\hline 2 & seed drill Unia Poznaniak & seed metering wheel (weedle hole - socket) \\
\hline 3 & $\begin{array}{l}\text { seed drill Famarol, Unia: Poznaniak, } \\
\text { Polonez }\end{array}$ & seed metering wheel A (to the pea seeds) \\
\hline 4 & $\begin{array}{l}\text { seeddrillFamarol, Unia: Poznaniak, } \\
\text { Polonez }\end{array}$ & cam I \\
\hline 5 & $\begin{array}{l}\text { seed drill Famarol, Unia: Poznaniak, } \\
\text { Polonez }\end{array}$ & cam II \\
\hline 6 & seed drill Amazone & standard seed metering wheel symbol: 3371100 \\
\hline 7 & seed drill Amazone: D7 & seed metering wheel, symbol: 3389100,3372100 \\
\hline 8 & seed drill Amazone: D8 & chain tensioner bearing, symbol: 3539400 \\
\hline 9 & seed drill Amazone: D7 & seed drill's planting apparatus casing, symbol: 3435100 \\
\hline 10 & seed drill Kongskilde Demeter Variosem & roller tensioner, symbol: 300010748 \\
\hline 11 & field sprayer & spray nozzle disc, slot $1 \mathrm{~mm}$ \\
\hline 12 & field sprayer & spray nozzle disc, slot $1.5 \mathrm{~mm}$ \\
\hline 13 & field sprayer & distributor long lever, type FERMO, DURO, GRAN \\
\hline 14 & field sprayer & distributor short lever, type FERMO, DURO, GRAN \\
\hline 15 & field sprayer Agromet Pilmet & hydraulic agitator framework \\
\hline
\end{tabular}

Table 3. Spare parts selected for production by using the FDM method [19, 20, 21].

\begin{tabular}{|c|c|c|c|c|}
\hline No. & Spare part & Distributor & Part's gross price & Part's minimum price (with delivery) \\
\hline \multirow{4}{*}{1} & \multirow{4}{*}{$\begin{array}{l}\text { seed metering } \\
\text { wheel (hexagonal } \\
\text { hole - socket) }\end{array}$} & I & $\begin{array}{l}3.46 \text { PLN, } \\
0.94 P L N\end{array}$ & $\begin{array}{c}23.46 \text { PLN, } \\
6.39 \text { PLN }\end{array}$ \\
\hline & & II & $\begin{array}{l}3.29 \text { PLN, } \\
0.90 \text { PLN }\end{array}$ & $\begin{array}{c}\text { 16.29 PLN, } \\
4.44 \text { PLN }\end{array}$ \\
\hline & & III & $\begin{array}{l}4.00 \text { PLN, } \\
1.09 \text { PLN }\end{array}$ & $\begin{array}{l}12.50 \text { PLN, } \\
3.41 \text { PLN }\end{array}$ \\
\hline & & Average & $\begin{array}{l}3.58 \text { PLN, } \\
0.98 \text { PLN }\end{array}$ & $\begin{array}{c}17.42 \text { PLN, } \\
4.75 \text { PLN }\end{array}$ \\
\hline \multirow{4}{*}{14} & \multirow{4}{*}{$\begin{array}{l}\text { distributor short } \\
\text { lever, type } \\
\text { FERMO, DURO, } \\
\text { GRAN }\end{array}$} & I & $\begin{array}{c}19.37 \text { PLN, } \\
5.28 \text { PLN }\end{array}$ & $\begin{array}{l}\text { 39.37 PLN, } \\
10.73 \text { PLN }\end{array}$ \\
\hline & & II & $\begin{array}{r}20.00 \text { PLN, } \\
5.45 \text { PLN }\end{array}$ & $\begin{array}{l}33.00 \text { PLN, } \\
\text { 8.99 PLN }\end{array}$ \\
\hline & & III & - & - \\
\hline & & Average & $\begin{array}{l}\text { 19.69 PLN, } \\
5.37 \text { PLN }\end{array}$ & $\begin{array}{c}\text { 36.19 PLN, } \\
\text { 9.86 PLN }\end{array}$ \\
\hline \multirow{4}{*}{15} & \multirow{4}{*}{$\begin{array}{l}\text { hydraulic agitator } \\
\text { framework }\end{array}$} & I & $\begin{array}{l}9.21 P L N, \\
2.51 P L N\end{array}$ & $\begin{array}{l}\text { 29.21 PLN, } \\
7.96 \text { PLN }\end{array}$ \\
\hline & & II & $\begin{array}{l}9.90 \text { PLN, } \\
\text { 2.70 PLN }\end{array}$ & $\begin{array}{l}22.90 \text { PLN, } \\
6.24 \text { PLN }\end{array}$ \\
\hline & & III & $\begin{array}{l}6.00 \text { PLN, } \\
1.63 \text { PLN }\end{array}$ & $\begin{array}{c}14.50 \text { PLN, } \\
3.95 \text { PLN }\end{array}$ \\
\hline & & Average & $\begin{array}{l}\text { 8.37 PLN, } \\
2.28 \text { PLN }\end{array}$ & $\begin{array}{c}22.20 \text { PLN, } \\
6.05 \text { PLN }\end{array}$ \\
\hline
\end{tabular}




\section{Results}

The geometry modeling and the FDM machine control code were prepared on the basis of real objects from agricultural machines applying of the Inventor. Parts were produced based on the STL files prepared by the authors. Documentation files contained the real geometry of the objects.STL files were sent to the work program of the FDM machine to the appropriate numerical control code. A machine with a closed but not heated working chamber - FlashForgeCreator Pro, was used to produce the samples. Figure 1 shows the production process of a hydraulic agitator framework with PLA material. The layer of thickness for all parts and materials was $0.25 \mathrm{~mm}$.

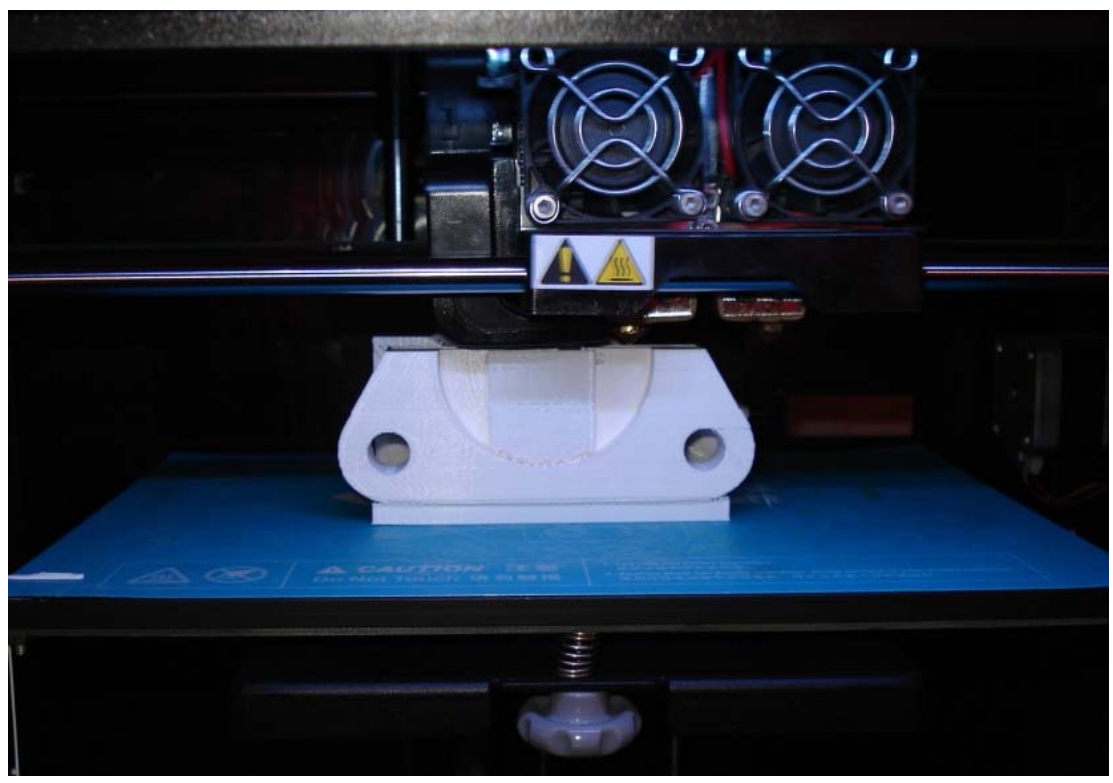

Fig.1. The process of producing spare with PLA material - hydraulic agitator framework.

Parts were produced in three variants - three thermoplastic materials. The materials used for the production and their cost are summarised in Tab.4. Prices of materials for the production process were determined based on the average market prices of their producers. Products whose producers were not known or did not have technical specification were omitted. These prices are given in retail. They do not take into account any promotions and discounts by a wholesale purchase. It is worth noticing that for years, the price of materials for FDM processes has been decreasing, in spite of the significant depreciation of money value in the same period.

Table 4. List of FDM materials use in the research [22, 23, 24].

\begin{tabular}{|c|c|c|c|c|c|c|}
\hline $\begin{array}{c}\text { Thermoplastic } \\
\text { material }\end{array}$ & $\begin{array}{c}\text { Trade } \\
\text { name }\end{array}$ & Producer & $\begin{array}{c}\text { Filament } \\
\text { thread } \\
\text { diameter } \\
\varnothing[\mathrm{mm}]\end{array}$ & $\begin{array}{c}\text { Mass } \\
{[\mathrm{g}]}\end{array}$ & Package price & $\begin{array}{c}100 \mathrm{~g} \text { of a } \\
\text { filament } \\
\text { price }\end{array}$ \\
\hline ABS & $\begin{array}{c}\text { Filament } \\
\text { ABS+ }\end{array}$ & $\begin{array}{c}\text { Devil } \\
\text { Design }\end{array}$ & 1.75 & 1000 & $\begin{array}{c}89.99 \text { PLN, } \\
24.52 \text { USD }\end{array}$ & $\begin{array}{c}9.00 \text { PLN, } \\
2.45 \text { USD }\end{array}$ \\
\hline PLA & $\begin{array}{c}\text { Filament } \\
\text { PLA }\end{array}$ & Spectrum & 1.75 & 1000 & $\begin{array}{c}79.99 \text { PLN, } \\
21.80 \text { USD }\end{array}$ & $\begin{array}{c}8.00 \text { PLN, } \\
2.18 \text { USD }\end{array}$ \\
\hline PETG & $\begin{array}{c}\text { PET-G } \\
\text { Standard }\end{array}$ & ROSA3D & 1.75 & 800 & $\begin{array}{c}66.50 \text { PLN, } \\
18.12 \text { USD }\end{array}$ & $\begin{array}{c}8.31 \text { PLN, } \\
2.26 \text { USD }\end{array}$ \\
\hline
\end{tabular}


Table 5 contains photographs of produced parts before and after the removal of the support material. For every part, the material from which it was produced was assigned.

Table 5. Produced spare parts.

Name
$\begin{gathered}\text { seed metering wheel } \\ \text { hexagonal hole - } \\ \text { socket) }\end{gathered}$

Table 6 contains the time of production of spare parts with the division of chosen thermoplastic material.

Table 6. Summary of working parameters and time of production.

\begin{tabular}{|c|c|c|c|c|}
\hline \multirow{2}{*}{$\begin{array}{c}\text { Part } \\
\text { No. }\end{array}$} & Part name & ABS & PLA & PETG \\
\cline { 2 - 5 } 1 & $\begin{array}{c}\text { seed metering wheel } \\
\text { (hexagonal hole }- \\
\text { socket) }\end{array}$ & $5 \mathrm{~h} 46 \mathrm{~min}$ & $5 \mathrm{~h} 46 \mathrm{~min}$ & $5 \mathrm{~h} 7 \mathrm{~min}$ \\
\hline 14 & $\begin{array}{c}\text { distributor short } \\
\text { lever, type FERMO, } \\
\text { DURO, GRAN }\end{array}$ & $2 \mathrm{~h} 55 \mathrm{~min}$ & $2 \mathrm{~h} 12 \mathrm{~min}$ & $1 \mathrm{~h} 51 \mathrm{~min}$ \\
\hline 15 & $\begin{array}{c}\text { Hydraulic agitator } \\
\text { framework }\end{array}$ & $5 \mathrm{~h} 13 \mathrm{~min}$ & $5 \mathrm{~h} 12 \mathrm{~min}$ & $4 \mathrm{~h} 31 \mathrm{~min}$ \\
\hline
\end{tabular}


Table 7 lists masses of all produced spare parts. The table contains the division into the mass of each product before processing and the mass of waste generated after finishing it. Supported materials constituted a majority of the waste.

Table 7. Mass of analysed spare parts.

\begin{tabular}{|c|c|c|c|c|c|c|c|c|c|}
\hline \multirow[b]{3}{*}{ No. } & \multicolumn{9}{|c|}{ Mass [g] } \\
\hline & \multicolumn{3}{|c|}{ ABS } & \multicolumn{3}{|c|}{ PLA } & \multicolumn{3}{|c|}{ PETG } \\
\hline & Total & $\begin{array}{l}\text { Sample } \\
\text { of } \\
\text { finished } \\
\text { product }\end{array}$ & Waste & Total & $\begin{array}{c}\text { Sample of } \\
\text { finished } \\
\text { product }\end{array}$ & Waste & Total & $\begin{array}{c}\text { Sample of } \\
\text { finished } \\
\text { product }\end{array}$ & Waste \\
\hline 1 & 91.170 & 71.698 & $\begin{array}{c}19.47 \\
2\end{array}$ & 123.821 & 99.258 & 24.562 & 132.296 & 105.955 & 26.341 \\
\hline 14 & 36.974 & 31.738 & 5.236 & 46.012 & 39.594 & 6.418 & 48.313 & 41.772 & 6.541 \\
\hline 15 & 66.148 & 58.584 & 7.564 & 89.373 & 81.19 & 8.183 & 78.477 & 69.687 & 8.79 \\
\hline
\end{tabular}

\section{Discussion}

Table 8 contains the time needed to produce each spare part under analysis. In minimum delivery time, was considered for ordered parts and in the case of produced parts - only the time of producing them on the FDM machine. In these cases, the time needed to build a model and all of the finishing processing was not taken into account.

Table 8.Comparison of the delivery and production time of the analysed spare parts.

\begin{tabular}{|c|c|c|c|c|c|}
\hline \multirow{2}{*}{$\begin{array}{l}\text { Part } \\
\text { No. }\end{array}$} & \multirow{2}{*}{ Part name } & \multirow{2}{*}{$\begin{array}{l}\text { Minimum } \\
\text { delivery time }\end{array}$} & \multicolumn{3}{|c|}{ Production time } \\
\hline & & & ABS & PLA & PETG \\
\hline 1 & $\begin{array}{l}\text { seed metering wheel } \\
\text { (hexagonal hole - } \\
\text { socket) }\end{array}$ & $24 h$ & $5 \mathrm{~h} 46 \mathrm{~min}$ & $5 \mathrm{~h} 46 \mathrm{~min}$ & $5 \mathrm{~h} 7 \mathrm{~min}$ \\
\hline 14 & $\begin{array}{l}\text { distributor short lever, } \\
\text { type FERMO, DURO, } \\
\text { GRAN }\end{array}$ & $24 h$ & $2 \mathrm{~h} 55 \mathrm{~min}$ & $2 \mathrm{~h} 12 \mathrm{~min}$ & $1 \mathrm{~h} 51 \mathrm{~min}$ \\
\hline 15 & $\begin{array}{l}\text { hydraulic agitator } \\
\text { framework }\end{array}$ & $24 h$ & $5 \mathrm{~h} 13 \mathrm{~min}$ & $5 \mathrm{~h} 12 \mathrm{~min}$ & $4 \mathrm{~h} 31 \mathrm{~min}$ \\
\hline
\end{tabular}

Production of single parts with the FDM method is at least several times faster than the time needed to produce and purchase their equivalents. It should also be noted that the minimum delivery time from the shop is never guaranteed. In cases where there is a lack of suitable parts in the shop supply, delivery time can definitely be longer. In addition, the specificity of agricultural work requires working all days of the week. Commercial and courier activities are different. Depending on the country's legal regulations, their services may be unavailable some days. Production of parts directly at the end-user site reduces the risk of extending the time of service works.

Considering economic profitability, it is crucial to take the scale of the demand for spare parts in a single farm into account. In the case of annual demand, when only several parts are needed, only the depreciation of the FDM machine will be significant. However, assuming that the FDM machine will be used intensively, this cost will not become essential. The practice of applying FDM machines in other industries 
indicates that the cost associated with the processed material is definitely the largest. It turns out that production of spare parts in the FDM machine is at least twice as cheap as buying an analogous part.

Table 9. Comparison of the production cost of spare parts depending on the production method.

\begin{tabular}{|c|c|c|c|c|c|}
\hline \multirow{2}{*}{$\begin{array}{l}\text { Part } \\
\text { No. }\end{array}$} & \multirow{2}{*}{ Part name } & \multirow{2}{*}{$\begin{array}{l}\text { Average price } \\
\text { (part }+ \text { delivery) }\end{array}$} & \multicolumn{3}{|c|}{ Material price } \\
\hline & & & ABS & PLA & PETG \\
\hline 1 & $\begin{array}{l}\text { seed metering wheel } \\
\text { (hexagonal hole - } \\
\text { socket) }\end{array}$ & $\begin{array}{l}\text { 17.42 PLN, } \\
4.75 U S D\end{array}$ & $\begin{array}{l}\text { 8.21 PLN, } \\
2.24 U S D\end{array}$ & $\begin{array}{l}\text { 9.91 PLN, } \\
\text { 2.70 USD }\end{array}$ & $\begin{array}{l}\text { 10.99 PLN, } \\
2.99 U S D\end{array}$ \\
\hline 14 & $\begin{array}{l}\text { distributor short lever, } \\
\text { type FERMO, DURO, } \\
\text { GRAN }\end{array}$ & $\begin{array}{l}36.19 P L N \\
9.86 U S D\end{array}$ & $\begin{array}{l}3.33 \text { PLN, } \\
0.91 U S D\end{array}$ & $\begin{array}{l}3.63 \text { PLN, } \\
0.99 U S D\end{array}$ & $\begin{array}{l}\text { 4.01 PLN, } \\
1.09 U S D\end{array}$ \\
\hline 15 & $\begin{array}{l}\text { hydraulic agitator } \\
\text { framework }\end{array}$ & $\begin{array}{l}22.20 \text { PLN, } \\
6.05 U S D\end{array}$ & $\begin{array}{l}\text { 5.95 PLN, } \\
1.62 \text { USD }\end{array}$ & $\begin{array}{l}\text { 7.15 PLN, } \\
1.95 U S D\end{array}$ & $\begin{array}{l}6.52 \text { PLN, } \\
1.78 U S D\end{array}$ \\
\hline
\end{tabular}

The approach for the production of spare parts suggested in this paper introduces substantial changes the logistic process for technical support in agriculture. Thanks to the FDM method, it becomes possible to produce spare parts independently. Until now, this has not been possible, mainly for structural and material reasons. However, it should be taken into account that before starting the production with the FDM, it is necessary to have a digital version of the part. Most importantly, the process of its creation requires competencies related to $\mathrm{CAD} / \mathrm{CAM}$, which is currently developed widely in the branch agriculture. As one of the solutions, it is possible to suggest buying relevant control codes for controlling the FDM machine. Preferably directly from the device producer. However, this generates additional, significant costs not taken into account in the research. The cost of purchase of such a CAD geometry or NC code would be single. Each subsequent production of the same part in the future would not be associated with incurring further expenses.

Servicing the FDM machine is not technically a complicated activity. However, it requires an appropriate training. In occasional cases of production, the depreciation of the FDM machine and maintenance influences, the price of spare parts. Remembering the issues associated with the need to have a digital model of the part, an approach, in which the implementation of additive manufacturing in agriculture should start with placing FDM machines in local service centres, not at individual farms, would be justified. In the near future, with the increasing availability of equipment and knowledge about spare parts, FDM machines could be used in service repair centres for individual farmers.

In the case of parts produced with the FDM method, the substantial endurance weakness is observed most often. It is most noticeable in the case of loading parts along the direction of the division into layers. In the case of a large number of agricultural spare parts under consideration, this problem can be solved by implementing additional changes to the construction of the parts. For example, it is possible to thicken the wall of the product in some chosen areas. The FDM production is much less limited by the geometrical complexity than standard technologies. However, the proceedings described above will not be possible when there is no physical space for thickening the wall of the part since the part mast cooperate with other parts of the machine. It is also possible to produce a part which is lighter than a conventionally manufactured part and at the same time has sufficient working parameters in places exposed to damage or wear thanks to applying the internal structure of FDM products, e.g. of 'honeycomb' type. There are many possibilities of producing various parts for agricultural machines. Therefore, future research should focus on a broader and more precise definition of the impact of technical and technological changes on the product manufactured by the FDM technique.

The research is based on the analysis of selected spare parts for two agricultural machines. Chosen machines are built from the type of plastics that perfectly fit the research problem. Many more examples of parts made of thermoplastics and other types of polymers can be found in widely understood agricultural equipment. Moreover, the FDM method of additive manufacturing indicated by the authors is only one among many alternatives. It was selected for analysis and described due to the fact that it is currently the most popular 
and most available method to an individual user. However, with the growing availability of other additive manufacturing methods, it may be possible to produce all components for machines and devices used in agriculture.

The authors checked the dimensional correctness of produced parts, obtaining values slightly different from the dimensions of objects available on the Polish market. Critical dimensions of produced parts are sufficient and allow their assembly on the appropriate agricultural machine. In the case of machining allowance, the thermoplastic material can be subjected to a removal treatment, e.g. by grinding.

\section{Conclusions}

The research conducted and described in this paper allowed the formulation of numerous and significant conclusions:

- FDM can constitute an alternative form of obtaining selected spare parts in agriculture.

- In the case of demand for a single part, the final cost can be smaller when applying the local FDM production method than getting the single part under the standard procedure for the supply chain.

- Machines in which the FDM method for the production of spare parts can be applied will increase with the technological developments of the FDM method, as well as with the availability of professional FDM machines for smaller business entities in the market of agriculture.

- The FDM method is characterised by better flexibility when producing agricultural spare parts than conventional techniques, especially for parts with composite geometrical structure.

- The possession and ability to operate the FDM machine is not sufficient enough to produce spare parts. It is essential to independently prepare or purchase a digital record of part geometry. In the initial stage, the would be implemented mainly in service centres or shops with agricultural spare parts. As the availability of the digital parts increases, having an FDM machine by individual farmers and self-production with manual replacement would be worth considering. Such an approach would shorten the service as much as possible.

- In cases of producing spare parts intended for sale, it may be problematic to resolve points related to patent protection. In cases of producing parts directly by the final user, this problem would definitely have a minor significance.

There exist many possibilities of producing spare part substitutes for agriculture. To fully determine the suitability of spare parts production in agricultural machinery using the FDM method, it is critical to carry out endurance tests. The authors are planning to conduct such studies in the form of standardised measurements and also in the normal life cycle of the product.

\section{References}

[1] Prajapati R.A., Dave K.H. and Raval K.H. (2021): Effect of fiber volume fraction on the impact strength of fiber reinforced polymer composites made by FDM process.- Materials Today: Proceedings, vol.1, Paper No.234158336. DOI:10.1016/J.MATPR.2020.12.262.

[2] Patalas-Maliszewska J., Topczak M. and Kłos S. (2020): The level of the additive manufacturing technology use in polish metal and automotive manufacturing enterprises.- Applied Sciences, vol.10, No.3, p.20. doi: https://doi.org/10.3390/app10030735

[3] Kosmol J., Kopytyński K., Lehrich K. and Dyrbuś G. (2008): Testing of the quality of production by means of rapid prototyping the FDM.- Scientific works of the Department of Machine Design. vol.3, pp.165-176. doi: bwmeta1.element.baztech-article-BSL1-0008-0024.

[4] Łukaszewski K., Wichniarek R. and Górski F. (2020): Determination of the elasticity modulus of additively manufactured wrist hand orthoses.- Materials, vol.13, No.19, p.18. doi: org/10.3390/ma13194379.

[5] Reza Khosravani M. and Reinicke T. (2020): Effects of raster layup and printing speed on strength of 3D-printed structural components.- Procedia Structural Integrity, vol.28, pp.720-725. doi: https://doi.org/10.1016/j.prostr.2020.10.083. 
[6] Markowski T., Budzik G., Kozik B. and Sobolewski B. (2014): Analysis of the possibility of producing gears with small modules using the FDM technology.- Mechanic, vol.02, pp.173-179. doi: 10.17814/mechanik.2015.12.582.

[7] Caban J., Szala M., Kęsik J. and Czuba Ł. (2017): The use of 3D printing in the automotive applications.- Buses: technology, exploitation, transport systems, Pub. Spatium, vol.6, pp.573-579. doi: bwmeta1.element.baztech0758c3a5-c61b-43f5-8575-a37b79ee8c0a.

[8] Coldwind G. and Jurczyk M. (2016): Practical Reverse Engineering. Methods, Techniques and Tools.- PWN Scientific Publisher. Warszawa.

[9] Wyleżoł M. (2006): Reverse engineering in design improvement. Engineering Modeling.- Department of Fundamentals of Machine Design, Silesian University of Technology.Gliwice, vol.1, No.32, pp.485-490. doi: bwmeta1.element.baztech-article-BSL9-0036-0069.

[10] Olejarczyk M. and Gruber K. (2015): The Influence of Temperatures Processing on the Mechanical Properties of Models in the FDM Technology.- Ed. J.Szrek: Interdisciplinarity of Scientific Research 2015.

[11] Mazurkiewicz A. (2017): Analysis of the print quality of an ABS thermoplastic element made in the FDM technology.- Buses: technology, exploitation, transport systems, Pub. Spatium, vol.18, No.6, pp.956-960. doibwmeta1.element.baztech-4e03fa85-85fa-4022-bf80-17386219bff7.

[12] Mydłowska K. and Tartakowski Z. (2015): Mechanical properties of products manufactured from polyamide with the FDM technology.- Plastics processing. Pub. Lukasiewicz Research Network - Institute for Engineering of Polymer Materials, vol.21, No.6, pp.467-472. doi: bwmeta1.element.baztech-e8ce0843-37c2-4311-bebcfa9dfac70774.

[13] Parafiniak M. and Żach P. (2016): Assessment of the peculiarities of materials used in the FDM technology.Mechanic, vol.12. doi: dx.doi.org/10.17814/mechanik.2016.12.552.

[14] Rybacki P., Rzeźnik C. and Buchwald T. (2013): Structure of planned technical services of agricultural tractors based on comparative studies.- Journal of Research and Applications in Agricultural Engineering. vol.58, No.2, pp.141-144. doi: bwmeta1.element.baztech-0b3bf2d6-2f27-4192-85bb-6bae86780c19.

[15] Wilde J. (2016): Prospects for the development of Polish beekeeping in the era of technological and health threats.VII Lublin Beekeeping Conference \& II International Beekeeping Symposium. Beekeeping in the industrial reality, Olsztyn.

[16] Hamrol A. (2017): Quality management and engineering. PWN Scientific Publisher. Warszawa.

[17] Hamrol A., Ciszak O., Legutko S. and Jurczyk M. (2018): Advances in Manufacturing.- Switzerland: Springer, Lecture Notes in Mechanical Engineering.

[18] NBP www.nbp.pl [access 12.2020].

[19] Agro-Bis Barszcz Sp.J. www.hurtowniarolnicza.pl [access: 09.2020].

[20] MIZAR www.sklep.mizar.com.pl [access: 09.2020].

[21] AGROKOM www.sklep-rolnicze.eu [access: 09.2020].

[22] www.botland.com.pl [access: 10.2020].

Received: March 3, 2021

Revised: August 24, 2021 